\title{
TURKEY BETWEEN SECULARIZATION AND PIETISM
}

\author{
Taha Niyazi Karaca1
}

\begin{abstract}
In Turkey, the secularization process has continued for over two hundred years without a successful conclusion. While part of the administrative group demands secularization, the other rigorously objects to this process. The main problem examined by this study is the conflict between these two groups. The core factors against secularization and the philosophical, juridical, and religious reasons influencing the process are discussed. The study focuses on past examples to analyze the secularization process. The study examines the main patterns in the process, starting with reflections on Nizam-1 Alem (Order of Universe), the philosophy of the foundation of Ottoman Empire, and the invariance principle. It continues with conclusions of the imperial edict of Gulhane (Tanzimat Fermani); then discussions on differences of civilization and culture in Turkey; and finally Mustafa Kemal Ataturk's beliefs on unique civilization and secularization. As a result, this paper presents the main problems of secularization in today's Turkey.
\end{abstract}

UDC Classification: 304 DOI: http://dx.doi.org/10.12955/cbup.v4.797

Keywords: secularism, Turkey, ottoman, pietism, order of universe, Ataturk's reforms.

\section{Introduction}

The secularization process has continued for two hundred years in Turkey. Along with this secularization process, two groups in Turkey have frequently clashed. While one group defends the idea of secularization, another group, whose thinking can be considered as pietism, strictly rejects this process. Some scholars start this secularization process with the foundation of a Republic on the account that the Ottoman Empire was a theocratic state. Some also reject this viewpoint. Therefore, there are deep differences among scholars for evaluating this process.

\section{Secularism and Pietism}

The word secularism is derived from the Latin word, 'saecularis', meaning worldly. Additionally, the various definitions of secularism can be classified as historical, political, sociological, ecclesiastical, and philosophical. Apart from this definition, there are these descriptions: "the State is a secular state which guarantees individual and corporate freedom of religion, deals with the individual as a citizen irrespective of his religion, is not constitutionally concerned to a particular religion - nor does it seek either to promote or interfere with religion" (Dressler \& Mandair, 2011).

It is a reflection movement against secularization and secularization of the church. The word piety comes from the Latin word, pietas, which in Latin usage, expresses a complex and highly valued Roman virtue; a man with pietas respected his responsibility to God and the country. "Pietism emphasized the need for a 'religion of the heart' instead of the head, and was characterized by purity, inward devotion, charity, asceticism, and mysticism” (Radical Pietism, n.d.).

In the wake of summarizing secularism and pietism, we describe the Turkish experience in the following sections.

\section{The Concept of Order of Universe or in Turkish Nizam-I Alem}

Although the new Turkey was founded in 1923, the state's roots extend back to the Ottoman period. In addition, certain ideas of governing and reign from the Ottoman Empire continued into the new Turkish Republic. These ideas are described as 'the concept of order of universe and unalterable principle'. To define the great Turkish transformation from the Ottoman Empire to the new secular Republic, one must understand the philosophy of the foundation of the Ottoman Empire and the unalterable principle.

According to the idea of the Ottoman ruling, the Sultan was appointed by God and the Sultan's main duty was to protect society, which was founded in order. That is, since God created every part of the universe for specific purposes, this unique part of the universe should remain as God willed. According to this idea, the first ruling principle concerning governing and reign was traditionalism. Any action deviating from the established tradition, whether or not it was derived from religious

\footnotetext{
${ }^{1}$ Taha Niyazi Karaca, Science and Letters Faculty, Bozok University, Turkey, tahaniyazikaraca@ gmail.com
} 
sources, was contrary to a supposed Ancient Law of Turkish Kanun-1 Kadim, which the şeriat, that is, religious law, was invoked to sanctify. The second ruling principle was that each group should be protected from effects which might disperse the order. The third ruling principle was the protection of the order. This principle was derived from the belief in the Order of the Universe, called in Turkish, 'Nizam-1 Alem' (Berkes, 1964).

According to the above principles, the status of the Sultan ranked the highest in the hierarchy. The Sultan was the shadow of God in the world and was attributed the title of Khalifa (Caliph). This title was a sign that described the highest religious rank. Thus, the Sultan was considered a person succeeding the prophet Mohammed. Apart from the Sultan, Turkish clergymen (ulema) had great significance, in a special role of maintaining the link between religion and state. The head was a mufti, called Shaykh al-Islām, whose function was to interpret the religious law when new cases arose. The assessments related not only to matters of religious policy, but also major concerns of the state, such as, declarations of war, relations with non-Muslim states, taxation, and innovations (e.g., the use of coffee or tobacco), and the introduction of inventions such as the printing press (Berkes, 1964; Sohreby, 1961; Shaw \& Shaw, 1977).

The specific concern of Turkish ulema was to ensure that the legislation, administration, and justice agreed (or not) with the religious law, called şeriat. Their main aim was the protection of the traditional order, i.e., not to allow any change or reformation movement. From the beginning of the seventeenth century, when unsettling of the order began, the ulema considered any innovation or reform movement as contrary to the religion. These ulema were fundamentalist, opposed, not only to all new reforms, but also the changes that had occurred in the past. They preached a return to the pristine injunctions of religion, inward devotion, asceticism, and mysticism, similar to the pietism demanded during 17th and 18th century in Europe (Taglia, 2015; Bozdoğan-Kasaba, 1997).

\section{The Two Steps for Secularism During Ottoman Period}

The first step for secularism during the Ottoman Period was to change traditionalism and the order of universe concept. In the late seventeenth century, the Ottoman Empire encountered many military failures. The rulers failed at each attempt to make reforms and because of these failures, the rulers or the statesmen decided to leave the order of universe idea and begin a new ruling idea, called the 'New Order'.

The rulers were aware of developments in the West for a new worldly order based on secular and rational principles, but they persisted in believing that the traditional system was basically sound and would eventually prove its superiority once technical ameliorations were implemented. As a consequence of this new idea, a new series of changes were triggered by Sultan Selim III. These innovations were named, 'Nizam-1 Cedid', meaning in English 'New Order'. The New Order conflicted with the Order of the Universe idea. Because new innovations were inspired by western countries, in their application, Sultan Selim III had to rely on the French and due to Western effects, the reforms could not succeed. Thus, in a short time, a rivalry group arose and a rebellion started. Clergymen regarded these new reforms as 'bidat', which is unbelief, or contrary to old order, the Order of the Universe idea. Sultan Selim III was killed by riots because of the innovations. In fact, this new idea, the New Order, was a supreme change for the Ottoman Empire's ruling system. In the wake of the death of Sultan Selim III, the New Order idea was proceeded by an edict of Sultan Abdulmecid. The Sultan proclaimed the new edict called, Tanzimat. In fact, Tanzimat was a different way of saying the New Order or Nizam-1 Cedid (Philliou, 2011; Tezcan, 2010).

The most significant reform emerged after this Tanzimat edict. The New Order produced new laws, new courts, and a new judicial process. For the first time in the Ottoman Empire, the Sultan placed himself as the bureaucratic legislative council above the religious law. Critical to this were the successes of the secular reforms in founding the Supreme Councils. Some consider that, with the Tanzimat edict, the Western constitutions were combined with Ottoman institutions. This meant that the state ruling concept and main principles were changed and belonged to a worldly order, not a religious law.

The second step emerged in 1876. This was a far significant change. In extraordinary conditions, Sultan Abdul Hamid II accepted a restriction on his rights to reign and promulgated the first constitution of the Ottoman Empire (Davidson, 2015). This new order and system was absolutely 
contrary to the Order of the Universe idea. Further, Sultan was no longer the shadow of God over the world and society. This case was a huge problem for Ottoman intellectuals and ulema. The new constitutional system was opposed to the old order concept. Therefore, intellectuals attempted to introduce compliance to this new system, with Şeria and Kuranic verses. A few intellectuals supported the constitution with a number of Hadis and Kuranic verses, such as "consult with them upon the affair" (Sure 3, verse 159) or "consult together in kindness" (Sure 65, verse 6). However, the majority of the ulema were opposed to the constitutional regime due to Islamic sensitiveness. The life of this new constitutional system was brief on account of the 1877-1878 Ottoman-Russian War. Sultan Abdul Hamid II abolished the constitution due to the extraordinary war conditions and did not call the Parliament until 1908. Sultan Abdul Hamid II ruled the Ottoman Empire singlehandedly during this period (Berkes, 1964).

In the wake of the Sultan's dethroning in 1909, the secular thinking extended among people by way of the Young Turks, the new power. Women's rights became a current issue during this period. The first women's association in Turkey, the Ottoman Welfare Organization of Women, was founded in 1909. Some new reforms relating to women, such as the monogamy law, and work permits were arranged by the Young Turks. These reforms and innovations were categorically regarded as secular changes for the Ottoman Empire (Tufan, 2000).

\section{Mustafa Kemal Ataturk's Reforms and Secular Republic}

After the national struggle between 1919 and 1923, Mustafa Kemal Ataturk became the president of the new republic. In a short time, a series of radical reforms commenced to secularize the state and social life. The Caliphate and the Ministry of Religious affairs were abolished in 1924. Religious sects (Tarikats) were prohibited in 1925. A new Civil Code, inspired by Western countries, was accepted in 1926. The most significant arrangement arose in 1928 when the Constitution was amended to delete the sentence stating that "the state's religion is Islam". Lastly, the principle of secularism was introduced into the Constitution in 1937. Along with these reforms arose other innovations, secularizing Turkish society. Especially, women's public places were changed and women gained many new rights affecting social, cultural, and economic life. After the death of Ataturk in 1938, these secularizing movements proceeded during the time with the Republican Party and even, the Democrat Party (Schull, Saraçolu, \& Zens, 2016).

\section{The Rising of the Islamic Discourses and New Islamic Demands}

New Islamic expressions, opposing secularization, developed after the coup d'état of 1980. The coup severely punished and suppressed the ideological differences. During the normalization period after the coup d'état, religion, Islamic references, and Islamic sects were prominently introduced into the Turkish society. The new Islamic discourses began to reflect a new identity that heavily combined religious and national entities. Apart from this, a new Anatolian bourgeoisie emerged during this period. Muslim entrepreneurs were well placed to prosper in this time. This new Muslim elite funded many prominent new publications and newspapers and many national and regional television stations. The economic liberalization and growth of the Turgut Özal period created a dynamic Anatolian entrepreneurial class and numerous opportunities in spaces, such as, in independent newspapers and television channels. These changing conditions emerged with a new Islamic class. Turgut Özal's liberal economic policies, and political liberalization, along with the introduction of new media technologies, had evolved a complex religious 'market' in Turkey. This new Islamic class and the Islamic sects were supported by the state against a pure nationalist class (Yavuz, 2009).

With growing social well-being and education, the new Islamic class began to demand more space in the public sphere. The new discourses emanating from the National Outlook Party rejected Western alliances and demanded to head the foreign policy for the Islamic world. Two main concepts affected these discourses. One was anti-imperialism and anti-westernization, and the second was antiSemitism. According to these expressions, Jews have controlled all economic and social life worldwide, and Western countries and Jews are allied against Turkey in order to collapse the country. To acquire power, Turkey has to face the Islamic world and become a large Islamic unity. New alliances will make Turkey an international power, as was the case with the Ottoman Empire. For this aim, Turkey has to reject secular reforms and proclaim the Caliphate that was abolished by Mustafa Kemal Ataturk. However, a Caliphate is greatly significant for all Islamic countries, especially today 
for the Islamic State of Iraq and Syria (ISIS). Many Islamic countries seek to secure the Caliphate as a power. The main struggle between Islamic countries is about gaining this power. In the case of Turkey, the Caliphate is an agent for returning command to the Ottoman society. Today, Turkey needs to resolve this rivalry between secularism and pietism and demands for becoming a more religious society. Indications suggest that Turkey has no other choice than to be on a stable road of secularism.

\section{Conclusion}

The principle of secularism was inspired by developments during the Ottoman society to create a modern society in which equality was guaranteed for all citizens without distinction on grounds of religion, denomination, or sex. It created an idea of a public sphere that would be more neutral, and as a neutral space, would avoid any visibility of religious signs or ethnic differences.

Secular reforms tried to teach a way of living, a way of thinking, a way of reasoning, and these became a vector of modernization towards Western civilization. Thus, it was not only a neutral concept of the public sphere, but also a modernist project.

There were three major terms pertaining to the secular reforms. Changing the philosophy of the foundation of the Ottoman Empire was the first term; a tremendously large breaking point. The New Order concept replaced the Order of the World. In this period, secular laws and new secular arrangements were carried into effect. The second term involved the new constitution and Parliament. The Sultan prorogued the Parliament on the grounds of wanting to be an Islamic symbol, as a Caliph. The third term was the proclamation of the Republic. A series of radical secular reforms were initiated during this period to secularize the state and social life.

A vast majority of the public considered the secularization process as 'faithlessness'. In the Turkish experience, the group opposed to the secularization process emphasized thoughts, such as inward devotion, asceticism and mysticism, similar to those of the European Pietist. The Caliphate and Şeria Laws still loom large in Turkey.

New Islamic discourses rejecting secularism began to grow in the late 1980's and these discourses have lasted until now. Many politicians and scholars have evaluated this anti-secular process as returning Islam to Turkey. One can express that Turkey walks a thin line between secularism and pietism.

\section{References}

Berkes, N. (1964). The Development of Secularism in Turkey. London. Hurst \& Company.

Bozdoğan, S., \& Kasaba, R. (1997). Rethinking Modernity and National Identity in Turkey, Washington. University of Washington.

Davidson, R. H. (2015). Reform in the Ottoman Empire 1856-1876, Princeton. Princeton University.

Dressler, M. \& Mandair, A. (2011). Secularism and Religion-Making. Oxford University Press.

Philliou, C. M. (2011). Biography of an Empire: Governing Ottomans in an Age of Revolution. University of California Press.

Radical Pietism. (n.d.). In Wikipedia Retrieved August 18, 2016, from: https://en.wikipedia.org/wiki/Radical_Pietism

Schull, K. F., Saraçolu, M. S., \& Zens, R. F. (2016). Law and Legality in the Ottoman Empire and Republic of Turkey, Indiana University Press.

Shaw, S., \& Shaw, K. (1977). History of Ottoman Empire and Modern Turkey, II. Cambridge, Cambridge University, Sohreby, N. (1961). Revolution and Constitutionalism in Ottoman Empire and Iran. Cambridge. Cambridge University Press. Taglia, S. (2015). Intellectuals and Reform in the Ottoman Empire: The Young Turks on the Challenges of Modernity, Routledge.

Tezcan, B. (2010). The Second Ottoman Empire: Political and Social Transformation in the Early Modern World. Cambridge University Press.

Turfan, N. (2000). Rise of the Young Turks: Politics, the Military and Ottoman Collapse, I. B. Tauris.

Yavuz, H. (2009). Secularism and Muslim Democracy in Turkey, University of Utah. 